\title{
Development of Combined Anaerobic-Aerobic System for Treating Industrial Molasses Wastewater
}

\author{
Narin PATTANANUWAT*, Toshikazu KAWAI**, Masashi HATAMOTO*, Kazuaki \\ SYUTSUBO $* * *$, Masanobu TAKAHASHI****, Hideki HARADA****, Takashi \\ YAMAGUCHI* \\ *Department of Environmental System Engineering, Nagaoka University of Technology, \\ 1603-1 Kamitomioka, Nagaoka, Niigata 940-2188, Japan \\ **Mitsui Sugar Co., Ltd., 1-2-14 Honson, Chigasaki, Kanagawa 253-0042, Japan \\ ***National Institute for Environmental Studies, 16-2 Onogawa, Tsukuba, Ibaraki 305-8506, \\ Japan \\ ****Department of Civil Engineering, Tohoku University, 6-6 Aoba, Sendai, Miyagi 980-8579, \\ Japan
}

\begin{abstract}
High-concentration industrial molasses wastewater treatment was examined using biological reactors coupled with physicochemical filtration membranes. The biological processes combined two mesophilic upflow anaerobic sludge blanket (UASB) reactors, a multi-stage upflow anaerobic sludge blanket (MS)-UASB, and a regular UASB for primary anaerobic pre-organic removal, and a downflow hanging sponge (DHS) reactor, equipped with polyurethane sponge media for post-aerobic treatment. Concentrated blackstrap molasses was diluted [12,000 - 1,500 $\mathrm{mg}$ of chemical oxygen demand (COD)/L] with organic loading rate (OLR) of 4.5 - 57.7 $\mathrm{kg}-\mathrm{COD} / \mathrm{m}^{3} / \mathrm{d}$ (MS-UASB), $2.3-34.7 \mathrm{~kg}-\mathrm{COD} / \mathrm{m}^{3} / \mathrm{d}$ (UASB), and $0.2-6.0 \mathrm{~kg}-\mathrm{COD} / \mathrm{m}^{3} / \mathrm{d}$ (DHS). A 1:1.3 recirculation ratio within the MS-UASB was evaluated at different influent concentrations for COD, biogas $\left(\mathrm{CH}_{4}\right)$ production, and nitrogen, phosphate, and color removal. The average total organic COD removal was over $92 \%$ with and without recirculation. A total of $150 \mathrm{NL} / \mathrm{d}$ of biogas with $64-75 \%$ methane content was collected at the maximum loading rate and influent concentration. Ammonia was reduced from $30 \mathrm{mg}-\mathrm{N} / \mathrm{L}$ to $5 \mathrm{mg}-\mathrm{N} / \mathrm{L}$ in the DHS reactor. The dark influent could not be reduced biologically; however, ultrafiltration and nanofiltration removed $98 \%$ of the color.
\end{abstract}

Keywords: biomethanation, decolorization, downflow hanging sponge reactor, molasses wastewater, multi-stage upflow anaerobic sludge blanket reactor, nutrient removal

\section{INTRODUCTION}

Molasses, a dark colored by-product of the sugar refining process, is considered to be one of the most recalcitrant agricultural products with a high concentration of organic matter (Satyawali and Balakrishnan, 2008). Due to the world's high consumption of molasses, a large amount of wastewater is generated during its manufacturing process (Saha et al., 2005). Conventional molasses wastewater treatments, including anaerobic lagoons and continuous stirred-tank reactor, have several major disadvantages such as large space requirements, longer hydraulic retention times (HRTs), and emission of methane and carbon dioxide as greenhouse gases into the atmosphere (Nandy et al., 2002). To avoid these pitfalls, biological anaerobic processes such as upflow anaerobic sludge blanket (UASB) reactors accompanied by an aerobic system, have been widely applied to industrial molasses-based distillery wastewater treatment (Mohana et al., 2009). The UASB system has been developed to successfully treat alcohol distillery wastewater with an organic loading rate of $20-30 \mathrm{~kg}-\mathrm{COD} / \mathrm{m}^{3} / \mathrm{d}$ under thermophilic conditions and produces a considerable amount of biogas (Harada et al., 1996). Other

Address correspondence to Narin Pattananuwat, Department of Environmental System Engineering, Nagaoka University of Technology, Email: narinovsky@gmail.com

Received May 7, 2013, Accepted August 6, 2013. 
mesophilic anaerobic treatments for molasses using reactors are reported to have an average organic loading rate (OLR) of $12 \mathrm{~g}-\mathrm{COD} / \mathrm{L} / \mathrm{d}$ with an average treatment efficiency of removed biochemical oxygen demand (BOD) and chemical oxygen demand (COD) and methane productivity of 79\%, 71\%, and $3.8 \mathrm{~L} / \mathrm{L}-$ reactor/d, respectively (Kucivilize, 2004). However, this system is incapable of treating highly concentrated wastewater to industrial discharge standards, and an aerobic post-treatment system is necessary to further treat the remaining substances. Thus, an aerobic downflow hanging sponge (DHS) system, designed for sewage treatment in developing countries, has been considered for combined operation with a UASB reactor (Tandukar et al., 2005). Wilkie et al. (2000) also summarized that thermophilic anaerobic digestion of alcohol stillage achieved similar treatment efficiencies and methane yields compared to mesophilic treatment. Furthermore, the physicochemical technology of ultrafiltration (UF) and nanofiltration (NF) spiral-wound membranes has been used to investigate the feasibility of degrading the dark brown pigments (Pant and Adholeya, 2007) and recovering remaining nutrients, since these membranes have recently been reported to have advantages over traditional approaches for large-scale removal of organics, nutrients, and dark-colored substances (Nataraj et al., 2006).

In this study, we evaluated the performance of combined biological processes and the feasibility of optional physicochemical systems using UASB/DHS and UF/NF membrane filtration, with particular focus on $\mathrm{COD}$, biogas production, nutrients $(\mathrm{N}$ and $\mathrm{P}$ ), and color removal. We also observed the sludge morphology to improve our understanding of the formation of granular sludge bulking ( $\mathrm{Li}$ et al., 2008) in carbohydrate-rich molasses-based wastewater treatment reactors.

\section{MATERIALS AND METHODS}

Experimental apparatus

Figure 1 shows a schematic diagram of the biological process unit, which was a

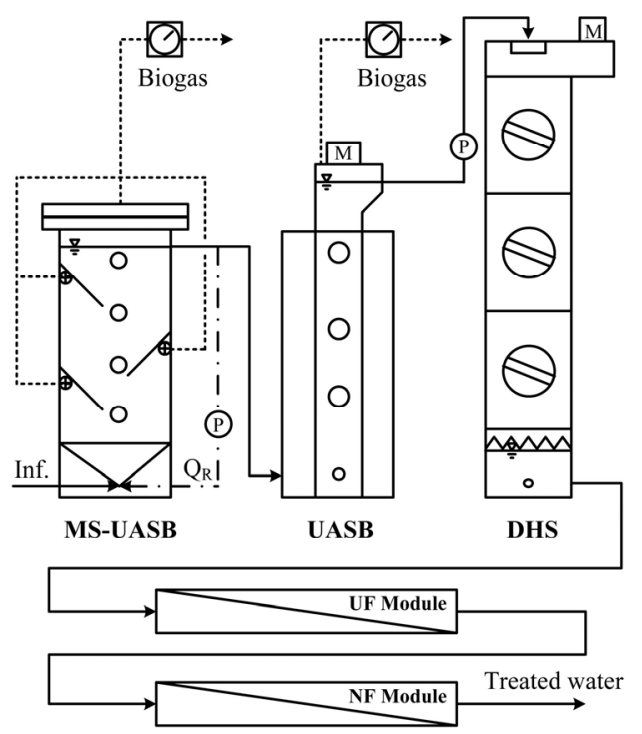

Inf. : Influent, $\mathrm{P}$ : Peristaltic pump, $\mathrm{M}:$ Motor for agitator (UASB), wastewater distributor (DHS), $Q_{R}$ : Recirculation

Fig. 1 - Flow diagram of the biological and physicochemical treatment processes. 
combination of a multi-stage (MS) UASB reactor $(10 \mathrm{~L})$ followed by regular-type (Reg) UASB (11 L) and DHS (18-L sponge capacity) reactors. The DHS reactor was filled with $ø 3.5 \times \mathrm{H} 3.5 \mathrm{~cm}$ polyurethane sponge media attached to the plastic sieve supporter. In the physicochemical process, 4 inches of spiral-wound UF and NF modules were employed to treat the effluent from the DHS reactor. Ultrafiltration modules outer vessel was made of fiber reinforced plastics (FRP) and installed with GE thin-film spiral-wound membrane GH8040F1001 which had molecular weight cut off (MWCO) of 2,500 Da (GE, USA), while NF module consisted of 4 inch-Bekaert side port PRO-4-300-SP outer vessel and TORAY spiral-wound SU220 polyamide composite membrane (TORAY, Japan). The microorganism biomass used as seeding for the reactors was digested sludge collected from a local municipal sewage treatment plant mixed with sludge from a non-molasses wastewater treatment reactor.

\section{Substrate}

The substrate used in the study was a dark brown, caramel-like form of blackstrap molasses with an original COD of $600,000-800,000 \mathrm{mg}-\mathrm{COD} / \mathrm{L}$ and was diluted to the setup concentration. Sodium bicarbonate $\left(\mathrm{NaHCO}_{3}: 2,500 \mathrm{mg} / \mathrm{L}\right)$ was also added as a buffer. The substrate was stored at the control temperature of $4^{\circ} \mathrm{C}$.

\section{Operational conditions}

The operational conditions of the biological processes were divided into nine phases P1 - P9 (Table 1), with P1 as the startup and steady period, and the influent concentration was gradually raised from 1,000 to $8,000 \mathrm{mg}-\mathrm{COD} / \mathrm{L}$. The influent concentration was increased to $10,000 \mathrm{mg}-\mathrm{COD} / \mathrm{L}$ in $\mathrm{P} 2$ without recirculation. In $\mathrm{P} 3$, the recirculation ratio of 1:1.3 was started with the same influent concentration as P2. The substrate concentration was reduced to $5,000 \mathrm{mg}-\mathrm{COD} / \mathrm{L}$ in $\mathrm{P} 4$ with $1: 1.3$ recirculation ratio for the recuperation. The substrate concentration was again constantly increased to 8,000 $\mathrm{mg}-\mathrm{COD} / \mathrm{L}$ as steady state. In P6, the same conditions as presented in P2 were conducted for the maximum organic loading without recirculation. The same substrate concentration of $10,000 \mathrm{mg}-\mathrm{COD} / \mathrm{L}$ was continuously applied without circulation in $\mathrm{P} 7$, however HRT was increased two-fold from P6. In P8, substrate concentration was reduced to $5,000 \mathrm{mg}-\mathrm{COD} / \mathrm{L}$ and maintained at recovery state before the final shock loading in $\mathrm{P} 9$.

Table 1 - Operational conditions for the biological processes.

\begin{tabular}{|c|c|c|c|c|c|c|c|c|}
\hline \multirow[b]{2}{*}{ Phase no. } & \multirow[b]{2}{*}{$\begin{array}{l}\text { Opt.period } \\
\text { [day] }\end{array}$} & \multirow{2}{*}{$\begin{array}{c}\text { COD conc. } \\
\text { (Before rec.) } \\
{[\mathrm{mg} / \mathrm{L}]}\end{array}$} & \multirow{2}{*}{$\begin{array}{l}\text { Rec. ratio } \\
{[\text { Rec.Q/Q] }}\end{array}$} & \multicolumn{4}{|c|}{ HRT } & \multirow[b]{2}{*}{$\begin{array}{l}\text { MS-UASB COD Loading } \\
{\left[\mathrm{kg}-\mathrm{COD} / \mathrm{m}^{3} / \mathrm{d}\right]}\end{array}$} \\
\hline & & & & $\begin{array}{c}\text { Total } \\
{[\mathrm{h}]}\end{array}$ & $\begin{array}{c}\text { MS-UASB } \\
{[\mathrm{h}]} \\
\end{array}$ & $\begin{array}{c}\text { UASB } \\
{[\mathrm{h}]}\end{array}$ & $\begin{array}{c}\text { DHS } \\
{[\mathrm{h}]} \\
\end{array}$ & \\
\hline 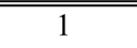 & 1 & $101,000-8,000$ & - & $=24.1$ & $\begin{array}{l}\sim 5.7 \\
\end{array}$ & $2 \sim 6.7$ & " $\sim 11.9$ & $\overline{5-36}$ \\
\hline 2 & $197-231$ & 10,000 & - & 21.7 & 5.3 & 6.1 & 10.3 & 51 \\
\hline 3 & $232-245$ & 10,000 & 1.3 & 18.7 & 2.3 & 6.1 & 10.3 & 87 \\
\hline 4 & $246-309$ & 5,000 & 1.3 & 18.7 & 2.3 & 6.1 & 10.3 & 29 \\
\hline 5 & $310-339$ & $6,000-8,000$ & 1.3 & 18.7 & 2.3 & 6.1 & 10.3 & $35-60$ \\
\hline 6 & $340-363$ & 10,000 & - & 21.7 & 5.3 & 6.1 & 10.3 & 50 \\
\hline 7 & $364-391$ & 10,000 & - & 43.4 & 10.6 & 12.2 & 20.6 & 23 \\
\hline 8 & $392-498$ & 5,000 & - & 21.7 & 5.3 & 6.1 & 10.3 & 23 \\
\hline 9 & $499-577$ & 10,000 & 1.3 & 18.7 & 2.3 & 6.1 & 10.3 & 76 \\
\hline
\end{tabular}

rec.: recirculation, opt.: opcration, Q: flow ratc, conc.: concentration 


\section{Biodegradability test}

The biodegradability test was conducted in order to investigate the substrate degradability of the seed sludge taken on day 0 and incubated in $122-\mathrm{mL}$ vials at $35^{\circ} \mathrm{C}$. All test sludge were withdrawn from reactor and purged with $\mathrm{N}_{2}$ gas to maintain anaerobic condition. Test sludge was rinsed with $25-\mathrm{mM}$ phosphate buffer at the test temperature and homogenized (Physcotron, Nichion, Japan). Hydrogen/carbon dioxide $(80: 20, \mathrm{v} / \mathrm{v})$, acetate, propionate and diluted molasses were used as substrate.

\section{Analytical methods}

Chemical oxygen demand concentration was determined using colorimetric method (DR5000 spectrophotometer, HACH, USA). Volatile fatty acids (VFA) were analyzed by gas chromatography (GC-1700, Shimadzu, Japan). Nutrients including $\mathrm{PO}_{4}{ }^{3-}-\mathrm{P}$, $\mathrm{NH}_{4}{ }^{-} \mathrm{N}, \mathrm{NO}_{2}{ }^{-}-\mathrm{N}, \mathrm{NO}_{3}{ }^{-}-\mathrm{N}$ were analyzed by high performance liquid chromatography (HPLC) (Prominence, Shimadzu). Biogas production was measured by a wet gas meter, and the composition was determined by gas chromatography (GC-8A, Shimadzu). The samples were filtered through a $\varnothing 0.45-\mu \mathrm{m}$ pore size filter paper to avoid fluctuating turbidity when measuring the color with a drainage coloration and turbidity meter (NDR2000; Nippon Denshoku, Japan). Morphological analysis of granular sludge was performed by scanning electron microscopy (SEM). Other analytical factors were monitored in accordance with Standard Methods for the Examination of Water and Wastewater (APHA, 2005).

\section{RESULTS AND DISCUSSION \\ Performance}

Figure 2 shows the time course of COD removal efficiency in the biological process, which achieved an average organic removal of more than $90 \%$ of COD and $95 \%$ of

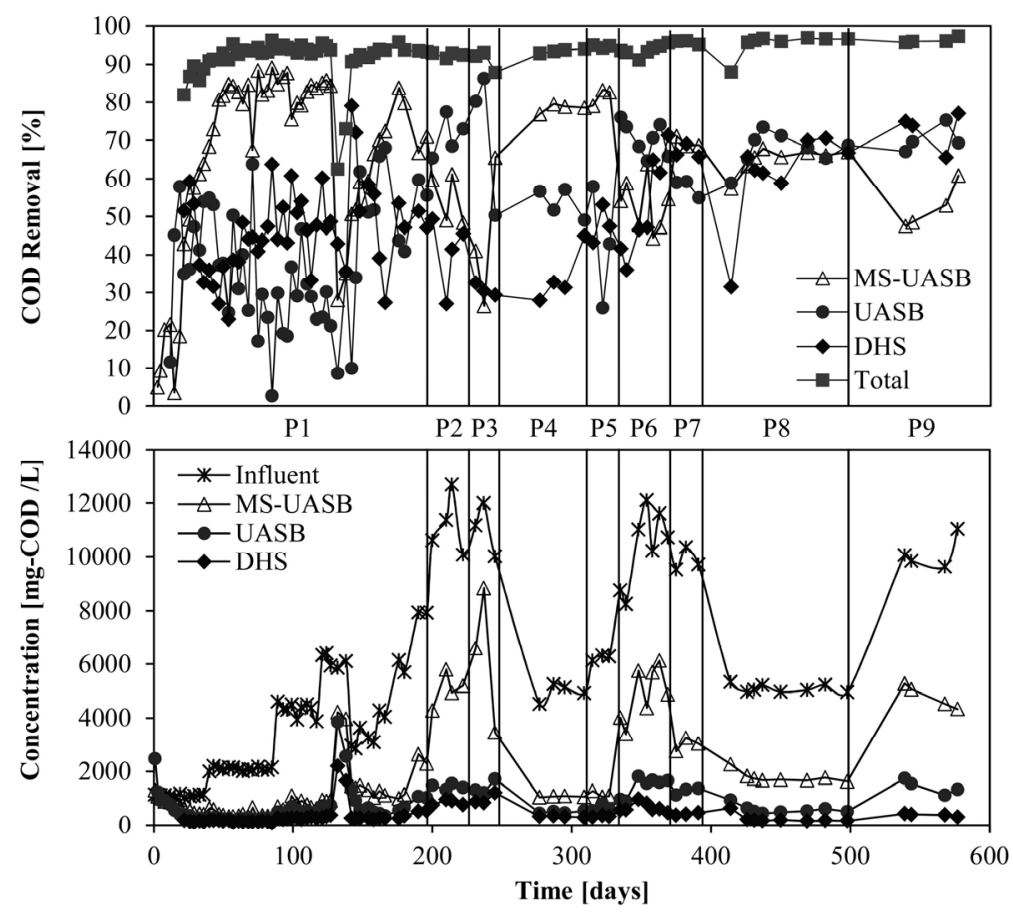

Fig. 2 - Time course of COD removal efficiency in the biological process. 
BOD. The maximum OLR of $57 \mathrm{~kg}-\mathrm{COD} / \mathrm{m}^{3} / \mathrm{d}$ (MS-UASB), $19 \mathrm{~kg}-\mathrm{COD} / \mathrm{m}^{3} / \mathrm{d}$ (UASB) and $2.1 \mathrm{~kg}-\mathrm{COD} / \mathrm{m}^{3} / \mathrm{d}$ (DHS) corresponded to a maximum influent concentration of $12,000 \mathrm{mg} \mathrm{COD} / \mathrm{L}$ with an HRT of $5 \mathrm{~h}$ in the MS-UASB, $6 \mathrm{~h}$ in the UASB, and $10 \mathrm{~h}$ in the DHS, respectively. In the membrane process, with $910 \mathrm{mg}-\mathrm{COD} / \mathrm{L}$ of effluent from the DHS as a feed, the UF and NF membranes achieved final effluent concentrations of $48 \mathrm{mg}-\mathrm{COD} / \mathrm{L}$ and $18 \mathrm{mg}-\mathrm{COD} / \mathrm{L}$, respectively.

On the $140^{\text {th }}$ day, the buffer was reduced (shock loading), and all three reactors showed the same effects from the $\mathrm{pH}$ drop, but recuperated in 14 days after the $\mathrm{pH}$ was adjusted to normal. During the $\mathrm{pH}$ shocking period, acetate accumulated from $15.1 \mathrm{mg} / \mathrm{L}$ to $1043.9 \mathrm{mg} / \mathrm{L}$ and propionate from $0 \mathrm{mg} / \mathrm{L}$ to $720.2 \mathrm{mg} / \mathrm{L}$, which was assumed to be due to the temporary inhibition of methane-producing bacteria. Chemical oxygen demand removal by the UASB and DHS reactors appeared to fluctuate. This resulted from the MS-UASB performance when most of the organic compounds were treated in the MS-UASB and the remaining compounds had relatively low concentrations (less than $1,000 \mathrm{mg}-\mathrm{COD} / \mathrm{L}$ ) that could lower the $\mathrm{F} / \mathrm{M}$ ratio of the system. In $\mathrm{P} 2$, the influent concentration was raised to $12,000 \mathrm{mg}-\mathrm{COD} / \mathrm{L}$, and the MS-UASB performance deteriorated due to the high OLR after the $200^{\text {th }}$ day, which resulted in the decrease of COD removal efficiency to $60 \%$. However, the UASB and DHS could recover the excessive loading and support a total removal of $90 \%$. When the recirculation ratio was 1:1.3 within the MS-UASB in P3 and the same 10,000 $\mathrm{mg}-\mathrm{COD} / \mathrm{L}$ of influent concentration was applied, COD removal was almost the same, but accumulated propionate decreased from its highest value of $1,120 \mathrm{mg} / \mathrm{L}$ in $\mathrm{P} 2(\mathrm{pH}$ shocks) to 670 $\mathrm{mg} / \mathrm{L}$ in $\mathrm{P} 3$ when recirculated (data not shown). In P4, the influent concentration was reduced to 5,000 $\mathrm{mg}-\mathrm{COD} / \mathrm{L}$ with the same overall HRT to lessen the loading stress and stabilize the system. Consequently, the recovery rate of the MS-UASB increased again to nearly $80 \%$, which led to a decrease of $50-55 \%$ in UASB and $30 \%$ in DHS removal efficiencies from the $246^{\text {th }}$ day. After system re-stabilization, the loading of each reactor was raised with the recirculation mode, and the performances of all reactors in the second half-period were different. As a result, the MS-UASB appeared to be enfeebled several times by the direct high loadings with concentrations of about 10,000 $\mathrm{mg}-\mathrm{COD} / \mathrm{L}$ and the amount of the granular seed sludge was enlarged and turned into bulking sludge floating out of the reactor. In contrast, the UASB and DHS efficiently recovered untreated organic matter, as revealed in P6. The removal percentages of the UASB and DHS reactors were higher, in contrast to the MS-UASB performance, which gradually decreased and remained in the range of $45-67 \%$. At the OLR of 30 $\mathrm{kg}-\mathrm{COD} / \mathrm{m}^{3} / \mathrm{d}$, a substrate concentration of $6,000 \mathrm{mg}-\mathrm{COD} / \mathrm{L}$ at the HRT of $5 \mathrm{~h}$ appeared to be the optimum condition for the MS-UASB to remove $80 \%$ of the COD removal percentage in this operation (Fig. 3).

Consequently, the UASB functioned as the pre-adjustment reactor before preceding the high COD concentration effluent entering the DHS reactor. The most suitable influent concentration for the UASB was between 2,000 mg-COD/L and 6,000 mg-COD/L, with a removal rate of $70 \%$ when the OLR could be raised to $20 \mathrm{~kg}-\mathrm{COD} / \mathrm{m}^{3} / \mathrm{d}$ (Fig. 4).

To further study the reactors' performance, the COD balances of both the UASB and DHS reactors at 5,000 and 10,000 $\mathrm{mg}-\mathrm{COD} / \mathrm{L}$ influent concentrations with and without recirculation were assessed. At a 5,000 mg-COD/L influent concentration (Fig. 5), 
wastewater was treated and converted by the main MS-UASB unit to methane gas more effectively with recirculation $(67 \%)$ than the non-recirculation mode $(36 \%)$ and the percentage removal was $75-80 \%$ compared with $65 \%$ removal efficiency in the non-recirculation mode. At a higher concentration of 10,000 mg-COD/L (Fig. 6), recirculation within the MS-UASB slightly increased the methane conversion from $51 \%$ to $61 \%$. This could have resulted from an insufficient recirculation ratio against the high concentration influent.
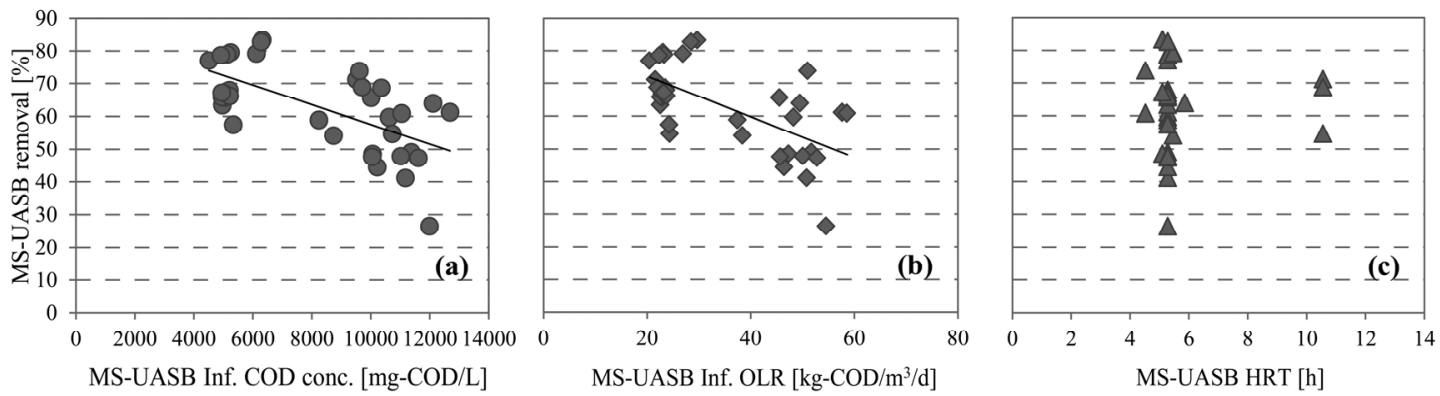

Fig. 3 - MS-UASB COD \% removal vs. influent (inf.) concentration (conc.) (a), OLR (b), and HRT (c).
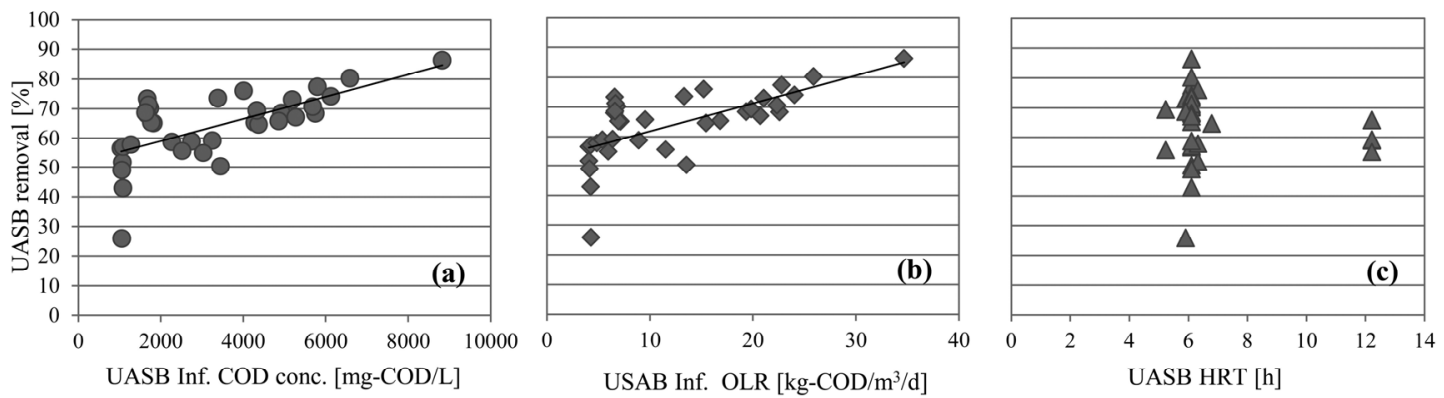

Fig. 4 - UASB COD \% removal vs. influent (inf.) concentration (conc.) (a), OLR (b), and HRT (c).
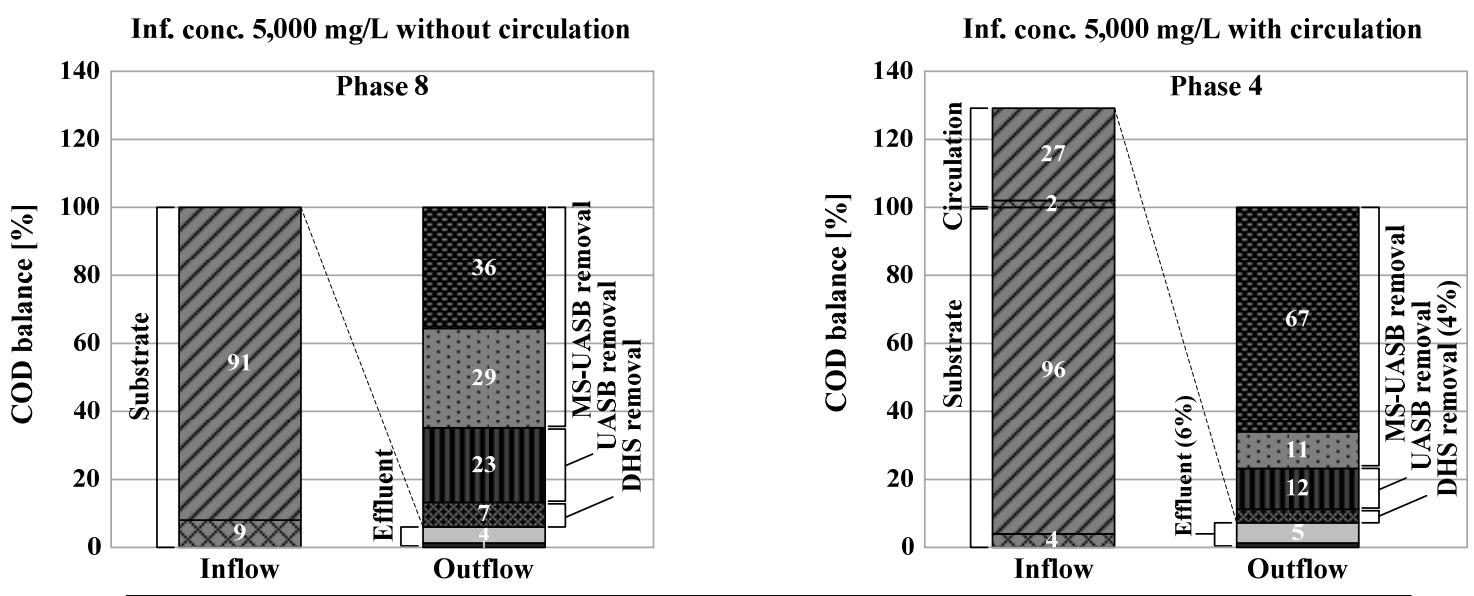

Q Particulate COD Soluble COD 䍝 Methane gas Dissolved methane, Assimilation, Reduction

II Removal by UASB (Including methane conversion and dissolved methane)

Removal by DHS

Fig. 5 - COD balance at 5,000 mg/L concentration. 


\section{Biodegradability test}

This test was performed to evaluate the biodegradability of the wastewater and the adaptability of sludge cultivated on different wastes for molasses wastewater treatment. Figure 7 indicates that molasses wastewater could be degraded and converted to methane gas with an initial $0.3 \mathrm{~g}-\mathrm{COD}-\mathrm{CH}_{4} / \mathrm{g}-\mathrm{VSS} / \mathrm{d}$ compared with other substrates.

\section{Color and nutrient removal}

Anaerobic bacteria are reported to have the ability to decompose the colored substance melanoidin in molasses spent wash (MSW). In fact, in Fig. 8, MS-UASB and UASB system decolorized approximately $10-15 \%$ of the substrate, it was reported that anaerobic bacteria produced some enzymes that could degrade melanoidin substances (Sirianuntapiboon et al., 2004). The color turned almost 50\% darker after treatment with the DHS reactor, which could have been due to repolymerization of the pigments. The UF/NF system showed significant removal of the molasses wastewater color, from

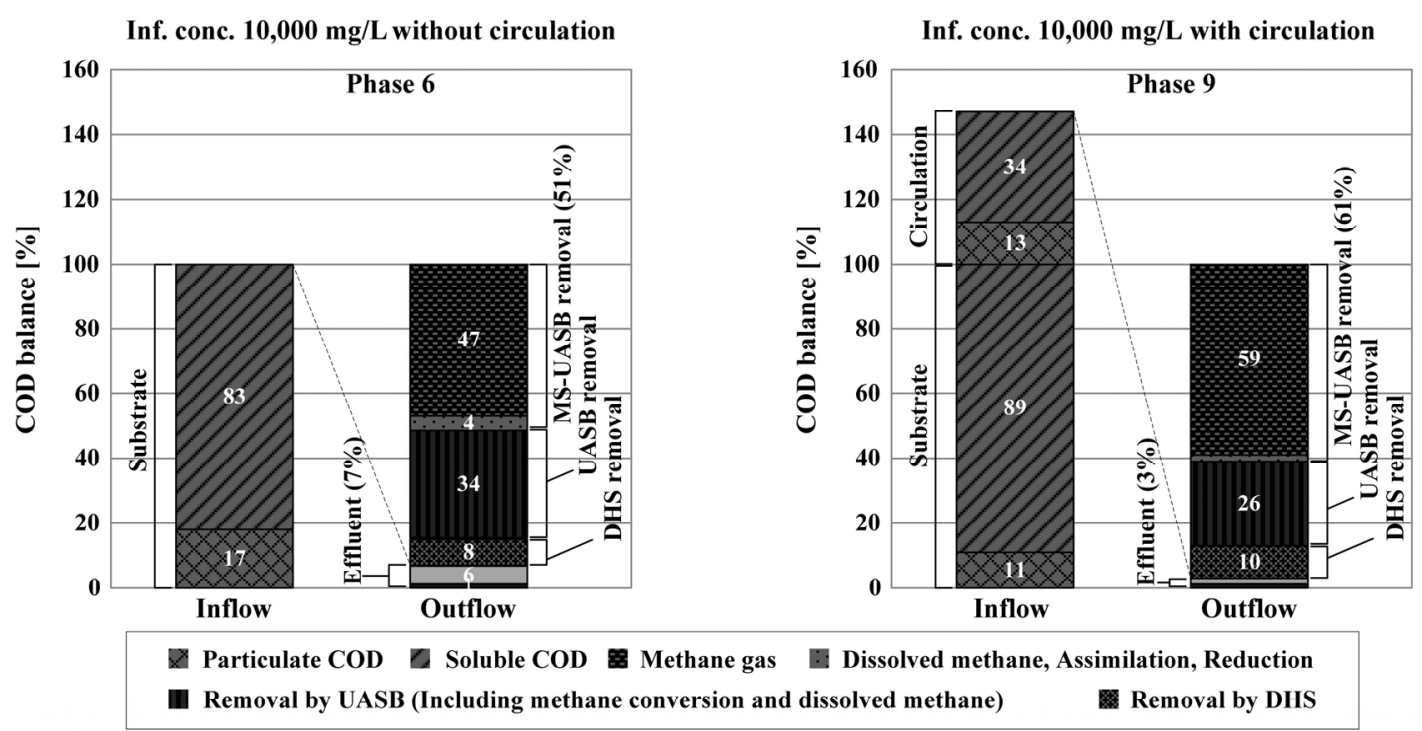

Fig. 6 - COD balance at 10,000 mg/L concentration.

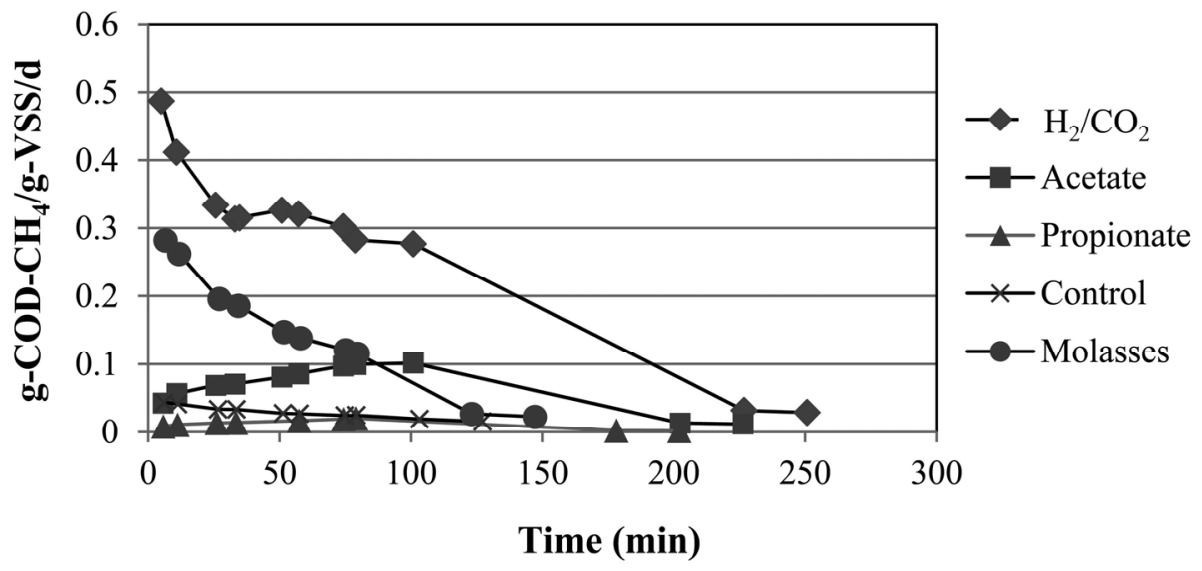

Fig. 7 - Biodegradability test. 
3,600 color units in the DHS effluent to 1 color unit (colorless; 99\% removal). Moreover, the experiments revealed the reduction of $\mathrm{PO}_{4}{ }^{3-}-\mathrm{P}$ from $48 \mathrm{mg}-\mathrm{P} / \mathrm{L}$ to 6 $\mathrm{mg}-\mathrm{P} / \mathrm{L}$ and of total nitrogen from $64 \mathrm{mg}-\mathrm{N} / \mathrm{L}$ to $37 \mathrm{mg}-\mathrm{N} / \mathrm{L}$, which were not removed by biological processes (Table 2 ).

\section{Microbial community}

Figure 9 shows SEMs of granular sludge taken from the $75^{\text {th }}$ day seed sludge. Clusters of round microorganisms morphologically similar to Methanosarcina sp. could be distinguished (Fig. 9a). These microorganisms were probably the predominant organisms from the previous treatment environment. In the $175^{\text {th }}$ day sludge sample, when sodium bicarbonate was added to the substrate to adjust the $\mathrm{pH}(7.5-8.0)$, Methanosaeta-like microorganisms were observed (Fig. 9b). Figure 9c shows filamentous microorganisms covering the outer surface of wash-out sludge taken at the $335^{\text {th }}$ day of operation. These microorganisms were possibly related to acid-forming bacteria that caused the biogas to be trapped inside the granular sludge and to flow up along with the stream.

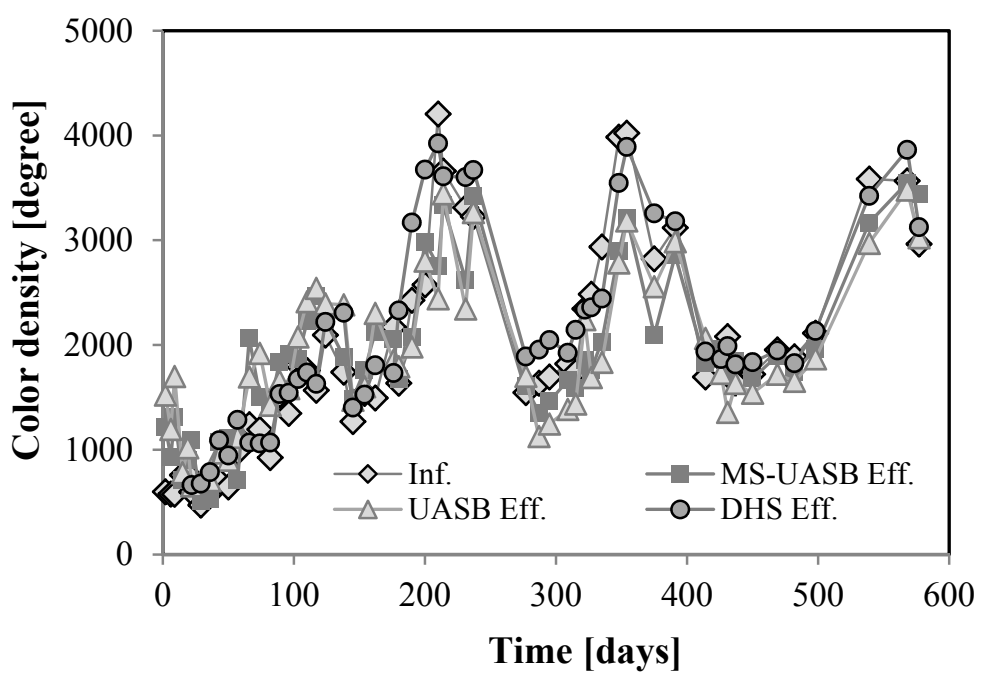

Fig. 8 - Color profile of biological processes.

Table 2 - $\mathrm{pH}, \mathrm{COD}$, color, and nutrient removal of the total system.

\begin{tabular}{|c|c|c|c|c|c|c|c|c|c|c|}
\hline \multicolumn{2}{|l|}{ Subject } & $\begin{array}{c}\mathrm{COD} \\
{[\mathrm{mg} / \mathrm{L}]}\end{array}$ & $\begin{array}{c}\text { BOD } \\
{[\mathrm{mg} / \mathrm{L}]}\end{array}$ & $\mathrm{pH}$ & $\begin{array}{c}\text { Color } \\
\text { [Degree] }\end{array}$ & $\mathrm{PO}_{4}-\mathrm{P}$ & $\mathrm{NO}_{2}-\mathrm{N}$ & $\begin{array}{l}\mathrm{NO}_{3}-\mathrm{N} \\
{[\mathrm{mg} / \mathrm{L}]}\end{array}$ & $\mathrm{NH}_{4}-\mathrm{N}$ & TKN \\
\hline \multicolumn{2}{|l|}{ Substrate } & 12,700 & 5,520 & 7.1 & 3,310 & 119 & 2 & 0 & 1 & 132 \\
\hline \multirow[t]{3}{*}{ Biological phase } & MS-UASB & 4,930 & 1,890 & 7.8 & 2,620 & 258 & 0 & 0 & 27 & 107 \\
\hline & Reg-UASB & 1,160 & 280 & 7.9 & 2,340 & 111 & 0 & 0 & 30 & 45 \\
\hline & DHS & 911 & 110 & 8.8 & 3,600 & 48 & 0 & 31 & 5 & 28 \\
\hline \multirow[t]{2}{*}{ Physicochemical phase } & UF & 48 & N.D. & 8.5 & 33 & 12 & 18 & 22 & 9 & 9 \\
\hline & $\mathrm{NF}$ & 18 & N.D. & 8.5 & 1 & 6 & 8 & 27 & 1 & 1 \\
\hline \multicolumn{2}{|c|}{ Industrial wastewater Standard } & 120 & 160 & $5.8 \sim 8.6$ & $100^{*}$ & 16 & & \multicolumn{2}{|c|}{120 as TN } & \\
\hline
\end{tabular}

* Standard: not objectionable ; 100 unit is an author's objective value, N.D. : Not Determined 

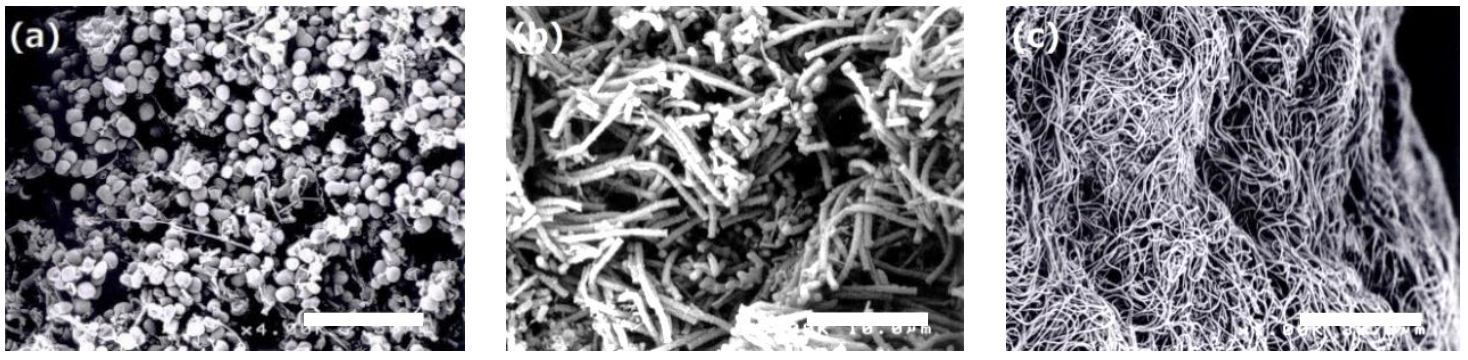

Fig. 9 - Morphological SEM observations of granular sludge from the MS-UASB reactor: (a) Methanosarcina-like microorganisms, scale bar $=7.50 \mu \mathrm{m}$; (b) Methanosaeta-like microorganisms, scale bar $=10.0 \mu \mathrm{m}$; (c) filamentous microorganisms at the surface of wash-out sludge, scale bar $=30.0 \mu \mathrm{m}$.

\section{CONCLUSIONS}

Over the 500 days of operation, the performance of the UASB/DHS process for the treatment of molasses-based spent wash wastewater was satisfactory, with $90 \%$ COD removal efficiency at a shortest total HRT of $18 \mathrm{~h}$ and the ability to cover from various critical conditions. The MS-UASB, which performed the main biological treatment, was able to treat MSW wastewater with a concentration of $6,000 \mathrm{mg}-\mathrm{COD} / \mathrm{L}$ and OLR of 20 $\mathrm{kg}-\mathrm{COD} / \mathrm{m}^{3} / \mathrm{d}$ at an HRT of $7 \mathrm{~h}$ at optimum stability. The UASB and DHS reactors also played significant roles by effectively backing up the MS-UASB in case of excessive loading at an OLR of $58 \mathrm{~kg}-\mathrm{COD} / \mathrm{m}^{3} / \mathrm{d}$. The application of the physicochemical membrane (UF/NF) proved to be a pragmatic approach, with 98\% COD removal and $99 \%$ color removal from the DHS effluent. The typical anaerobic microorganisms reported in the literature could be observed by SEM. Methanosarcina-like microorganisms, Methanosaeta-like microorganisms and filamentous microorganisms were distinguished, but these will require further analysis by microbiological methods, such as $16 \mathrm{~S}$ rRNA, to elucidate the phylogenetic details. The biological process appeared to be capable of treating the MSW wastewater for organic matter and nitrogen removal with nitrification within the DHS at a total OLR of $15 \mathrm{~kg}-\mathrm{COD} / \mathrm{m}^{3} / \mathrm{d}$ and an HRT of $24 \mathrm{~h}$; whereas the membrane process demonstrated remarkable color and phosphate removal efficiency. Therefore, this combined biological and physicochemical treatment system could achieve optimum performance in meeting the industrial wastewater standard.

\section{REFERENCES}

APHA (2005) Standard Methods for the Examination of Water and Wastewater, 21st ed. American Public Health Association, Washington DC, USA.

Harada H., Uemura S., Chen A. C. and Jayadevan J. (1996) Anaerobic treatment of a recalcitrant distillery wastewater by a thermophilic UASB reactor. Biores. Technol., 55(3), 215-221.

Kucivilize P. (2004) Super High Rate Anaerobic Wastewater Treatment by Thermophilic Multi-Stage UASB Reactor. PhD thesis, Department of Environmental System Engineering, Nagaoka University of Technology, Japan.

Li J., Hu B., Zheng P., Qaisar M. and Mei L. (2008) Filamentous granular sludge 
bulking in a laboratory scale UASB reactor. Biores. Technol., 99(9), 3431-3438.

Mohana S., Acharya B. K. and Madamwar D. (2009) Distillery spent wash: Treatment technologies and potential applications. J. Hazardous Materials, 163(1), 12-25.

Nandy T., Shastry S. and Kaul S. N. (2002) Wastewater management in a cane molasses distillery involving bioresource recovery. J. Environ. Manage., 65(1), 25-38.

Nataraj S. K., Hosamani K. M. and Aminabhavi T. M. (2006) Distillery wastewater treatment by the membrane-based nanofiltration and reverse osmosis processes. Water Res., 40(12), 2349-2356.

Pant D. and Adholeya A. (2007) Biological approaches for treatment of distillery wastewater: A review. Biores. Technol., 98(12), 2321-2334.

Saha N. K., Balakrishnan M. and Batra V. S. (2005) Improving industrial water use: case study for an Indian distillery. Resources Conservation Recycling, 43(2), 163-174.

Satyawali Y. and Balakrishnan M. (2008) Wastewater treatment in molasses-based alcohol distilleries for COD and color removal: A review. J. Environ. Manage., 86(3), 481-497.

Sirianuntapiboon S., Phothilangka P. and Ohmomo S. (2004) Decolorization of molasses wastewater by a strain No.BP103 of acetogenic bacteria. Biores. Technol., 92(1), 31-39.

Tandukar M., Uemura S., Machdar I., Ohashi A. and Harada H. (2005) A low-cost municipal sewage treatment system with a combination of UASB and the "fourth-generation" downflow hanging sponge reactors. Water Sci. Technol., 52(1-2), 323-329.

Wilkie A. C., Riedesel K. J. and Owens J. M. (2000) Stillage characterization and anaerobic treatment of ethanol stillage from conventional and cellulosic feedstocks. Biomass Bioenergy, 19(2), 63-102. 